\title{
Ring-cleavage of Phthalidisoquinoline Alkaloids by Ethyl Chloroformate ${ }^{* * *}$
}

\author{
Silvia von Angerer, Erwin von Angerer, Reinhard Ambros, and Wolfgang Wiegrebe* \\ Institute of Pharmacy, University, P. O. Box 357, D-8400 Regensburg, Germany
}

Received May 13, 1991

Degradation of (-)- $\alpha$-narcotine (5), (-)- $\beta$-narcotine (6), and (-)- $\beta$-hydrastine (7) with ethyl chloroformate (ECF) affords the chloro-urethans 9 and 18, respectively. Diastereomer 9-I is easily hydrolyzed to the hydroxy-urethan 10 , whilst 18 is converted to the methoxy-analogue 19. The stilbene lactone 11 is obtained from 9-I by treatment with DBU, the analogous stilbene 17 arises already when 7 is reacted with ECF. - Hydroxy-urethan 10 - a phenylogous aldol - is split by $\mathrm{OH}^{-}$to aldehyde 13 and to meconine (14). $\mathrm{LiAlH}_{4}$ reduction of 10 yields the stereochemically homogenous triol 15 , which is cyclized to diastereomers of the 3-phenyl-isochroman 16 under acidic conditions.
Ringöffnung von Phthalidisochinolin-Alkaloiden durch Chlorameisensäureethylester

Der Abbau von (-)- $\alpha$-Narkotin (5), (-)- $\beta$-Narkotin (6) und (-)- $\beta$-Hydrastin (7) mit Chlorameisensäureethylester (ECF) führt zu den Chlorurethanen 9 bzw. 18. Das Diastereomer 9-I reagiert leicht zum Hydroxyurethan 10, 18 zum Methoxy-Analogen 19. Chlorurethan 9-I bildet mit DBU das Stilbenlacton 11, aus 7 entsteht das analoge Stilben 17 bereits beim ECF-Abbau. - Hydroxyurethan 10 (ein phenyloges Aldol) wird durch Basen zum Aldehyd 13 und Mekonin (14) gespalten. $\mathrm{LiAlH}_{4}$ reduziert 10 zum sterisch einheitlichen Triol 15, das $\mathrm{H}^{+}$-katalysiert zu Diastereomeren des 3-Phenylisochromans 16 zyklisiert wird.
Gadamer and $K$ noch ${ }^{1)}$ have introduced ethyl chloroformate (ECF) for the benzylic cleavage of $\mathrm{N}$-alkylated 1,2,3,4-tetrahydroisoquinolines; von Bruchhausen and $\mathrm{Knabe}^{2)}$ have overcome the obstacle ${ }^{1)}$ that the urethan moiety so obtained could not be hydrolyzed to the corresponding secondary amine by reducing the carbamate with $\mathrm{LiAlH}_{4}$, and Knabe and Shukla ${ }^{3}$ ) have studied the electronic requirements for the cleavage of benzylamines in general. Some more aspects of von Bruchhausen's experiments are compiled in a review ${ }^{4}$.

We have repeated ${ }^{5)}$ Gadamer's experiments with laudanosine (1) and isolated the chloro-urethan 2 , the intermediate in the formation of stilbene 3 from laudanosine $(1)^{1,2)}$ as postulated by Gadamer $^{1)}$. Neither the absolute configuration nor the optical purity of chloro-urethan 2 could be deter-<smiles>[R]c1ccc(CC2(Cc3ccc([R])c([R])c3)c3cc([R])c([R])cc3CCN2C)cc1[R]</smiles>

$\underline{R-(-)-1}$

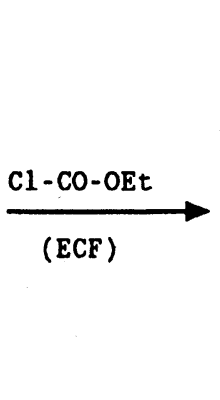<smiles>[R]c1ccc(CC(Cl)c2cc([R])c([R])cc2CCN(C)C(=O)OCC)cc1[R]</smiles>

$\underline{2}$

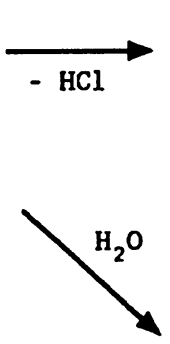

Scheme 1

$\mathrm{R}=\mathrm{OCH}_{3}$<smiles>[R]c1ccc(CC(O)c2cc([R])c([R])cc2CCN(C)C(=O)OCC)cc1[R]</smiles>

*) Part of the PhD-thesis S. von Angerer, née Prior, Regensburg, 1980.

**) Dedicated with warm regards to Prof. Dr. J. Sauer, Regensburg, on the occasion of his 60 . birthday. 
<smiles></smiles>

$$
\begin{aligned}
& \text { 5: } \mathrm{R}=\mathrm{OCH}_{3}[\underline{(-)-5:} 1 \mathrm{R}, 9 \mathrm{~S}] \\
& \text { 7: } \mathrm{R}=\mathrm{H} \quad[\underline{(-)-7:} 1 \mathrm{R}, 9 \mathrm{~S}] \\
& \text { Scheme } 2
\end{aligned}
$$

mined up to now (vide infra). The hydroxy-urethan 4 was obtained from 2 by hydrolysis or under more vigorous conditions with ECF from 1 with a 47:53-ratio of enantiomers ${ }^{5}$.

These findings prompted us to study the degradation of $\alpha$-narcotine (5), $\beta$-narcotine (6), and $\beta$-hydrastine (7); these alkaloids are characterized by an additional centre of chirality in their lactone parts (C-9), in direct neighbourhood of the chiral centre under consideration.

A similar reaction has been performed with (-)- $\alpha-5$ and (+)- $\beta$-narcotine (6), respectively, by Kerekes, Gaál, et al. ${ }^{6)}$ using BrCN: under solvolytic conditions they obtained the same hydroxylated cyanamide 8 from $(-)-5$ and (+)-6. X-ray analysis of 8 obtained from (+)- $\beta$-narcotine ((+)-6, $1 S$, 9S) revealed $1 \mathrm{~S}, 9 \mathrm{~S}$-configuration for this " $N$-cyano-1-hydroxy-1,2-seconarcotine" $(8)^{7)}$. The authors discuss the stereochemical course of their reactions ${ }^{6}$.<smiles>COc1ccc2c(c1OC)C(=O)O[C@H]2[C@H]1c2c(cc3c(c2OC)OCO3)CCN1C</smiles>

$6[\underline{(-)-6: 1 R, 9 R]}$
We used Gadamer's conditions (ECF; $\mathrm{CHCl}_{3} / \mathrm{Et}_{2} \mathrm{O}$ 1:1vol.; $15 \% \mathrm{KOH})^{1)}$ for the cleavage of $(-)-\alpha$-narcotine (5) and obtained a rather stable chlorine containing compound with an urethan- $\left(1695 \mathrm{~cm}^{-1}\right)$ and a five-membered lactone$\left(1760 \mathrm{~cm}^{-1}\right)$ absorption in its IR-spectrum. The ${ }^{1} \mathrm{H}-\mathrm{NMR}-$ spectrum revealed an ethyl increment, the $\mathrm{N}-\mathrm{CH}_{3}$ singlet of the former $\alpha$-narcotine (5) now resonated at lower field strength (cf. Experim. Part). These data are in agreement with structure 9. - $\mathrm{HPLC}$-analysis $\left(\mathrm{SiO}_{2} ; \mathrm{CH}_{2} \mathrm{Cl}_{2} / \mathrm{Et}_{2} \mathrm{O}\right.$ 1:4) showed that the reaction is highly stereoselective producing the diastereomeric urethans 9 in a 93:7 ratio, with $[\alpha]_{D}^{20}=$ $-8^{\circ}\left(\mathrm{CHCl}_{3}\right)$ for the main product (9-I). We tried to convert 9-I into 9-minor product (9-II) under the conditions described in Table 1, but - with the exception of entry 6- 9-I was recovered with the optical rotation unchanged.<smiles>COc1ccc2c(c1OC)C(=O)OC2C(O)c1c(CCN(C)C)cc2c(c1OC)OCO2</smiles>

Scheme 3<smiles>CCOC(=O)N(C)CCc1cc2c(c(OC)c1[C@H](Cl)[C@H]1OC(=O)c3c1ccc(OC)c3OC)OCO2</smiles>

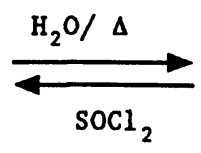<smiles>CCOC(=O)N(C)CCc1cc2c(c(OC)c1C(O)[C@@H]1OC(=O)c3c1ccc(OC)c3OC)OCO2</smiles> 
Table 1: Stereochemical Stability of Urethan 9-I. Chloro-urethan 9-I was treated under the conditions cited, the mixtures were analyzed by HPLC (cf. Experim. Part), rotations were measured directly (no work-up*)).

\begin{tabular}{clcc}
\hline Entry & Conditions & Results & Rotation \\
\hline 1 & acetone absol.; r.t. & a & b \\
2 & NaI; acetone absol.; r.t. & a & b \\
3 & LiCl; 1,2-dimethoxyethane absol.; & a & b \\
& r.t. & & \\
4 & LiCl + $\mathrm{AlCl}_{3}$; 1,2-dimethoxyethane & a & b \\
& absol.; r.t. & & \\
5 & NaI; 1,2-dimethoxyethane; r.t. & a & b \\
6 & NaI; acetone absol.; reflux & c & d \\
\hline
\end{tabular}

a: no reaction

b: rotation unchanged

c: formation of stilbene $\mathbf{1 1}$

d: rotation zero (see c)

*) Work-up affords carbinol 10

Heating the chloro-urethan 9-I with water or treatment with moist $\mathrm{Ag}_{2} \mathrm{O}$ in dioxan produced the hydroxy-urethan 10. In the meantime Lee et al. ${ }^{8)}$ have prepared this compound by a different procedure and have established its stereochemistry $(\alpha S, 9 S)$ by $\mathrm{X}$-ray analysis. Compound 10 is also obtained on prolonged reaction of $\alpha$-narcotine (5) with $\mathrm{ECF} / \mathrm{KOH}$ in $\mathrm{CHCl}_{3} / \mathrm{Et}_{2} \mathrm{O}$. - Treatment of the hydroxy-urethan 10 with $\mathrm{SOCl}_{2}$ regenerated the chloro-urethan 9-I $\left([\alpha]_{\mathrm{D}}^{20}=-8^{\circ}\left(\mathrm{CHCl}_{3}\right)\right)$.
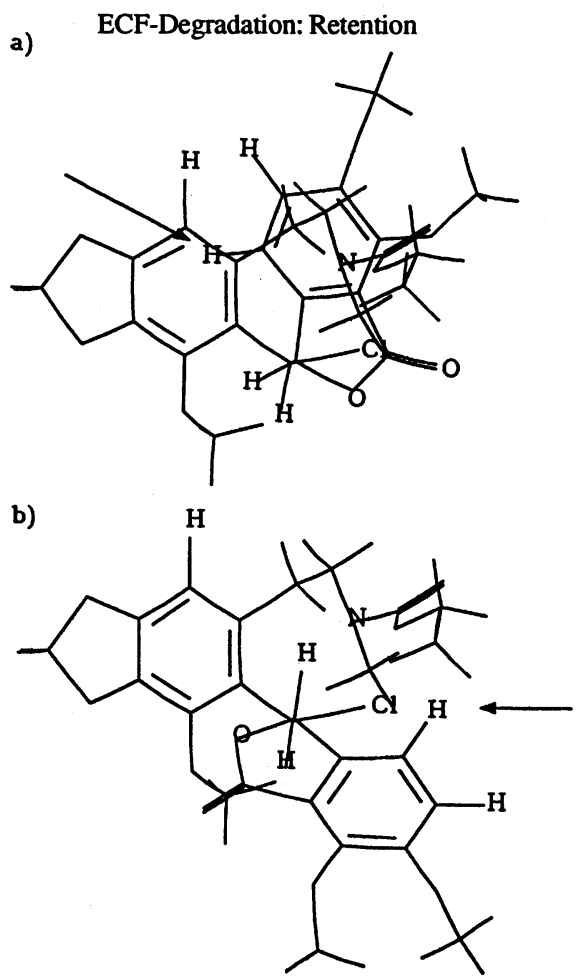

a)

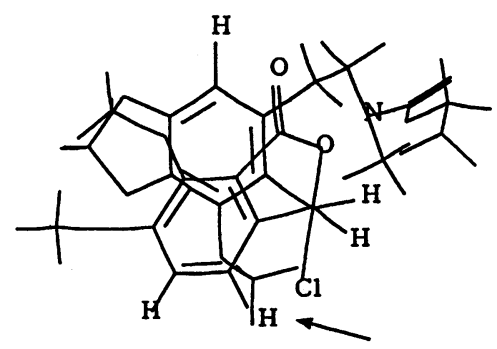

b)

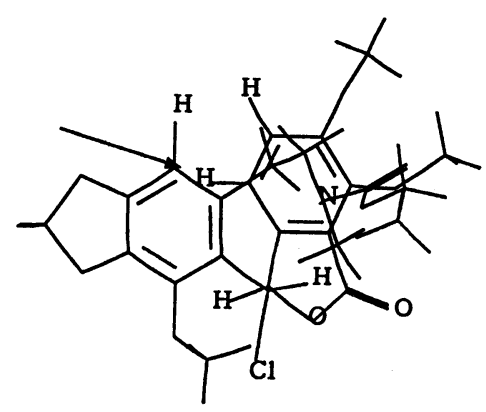

Fig. 1: Energetically favoured conformations a and $b$ for 9-I following ECF-degradation of 5 either with retention or inversion.

\footnotetext{
${ }^{\text {*) }}$ The Figures were plotted using ALCHEMY II (TRIPOS) program, the torsion angles were calculated with SYBYL and transfered. The conformations of the side chain and the methoxy groups were not fitted perfectly, because they do not affect the stereochemistry of the centers of chirality.
} 


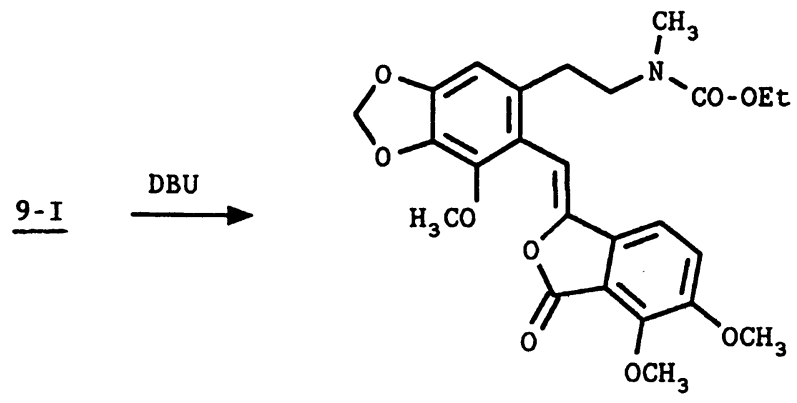

11

$\stackrel{(-)-6}{\underset{(c f .5)}{\stackrel{\text { ECF }}{\longrightarrow}} \text { 9-III }}+$<smiles>CCOC(=O)N(C)CCc1cc2c(c(OC)c1C(Cl)[C@H]1OC(=O)c3c1ccc(OC)c3OC)OCO2</smiles>

Scheme 5

9-IV
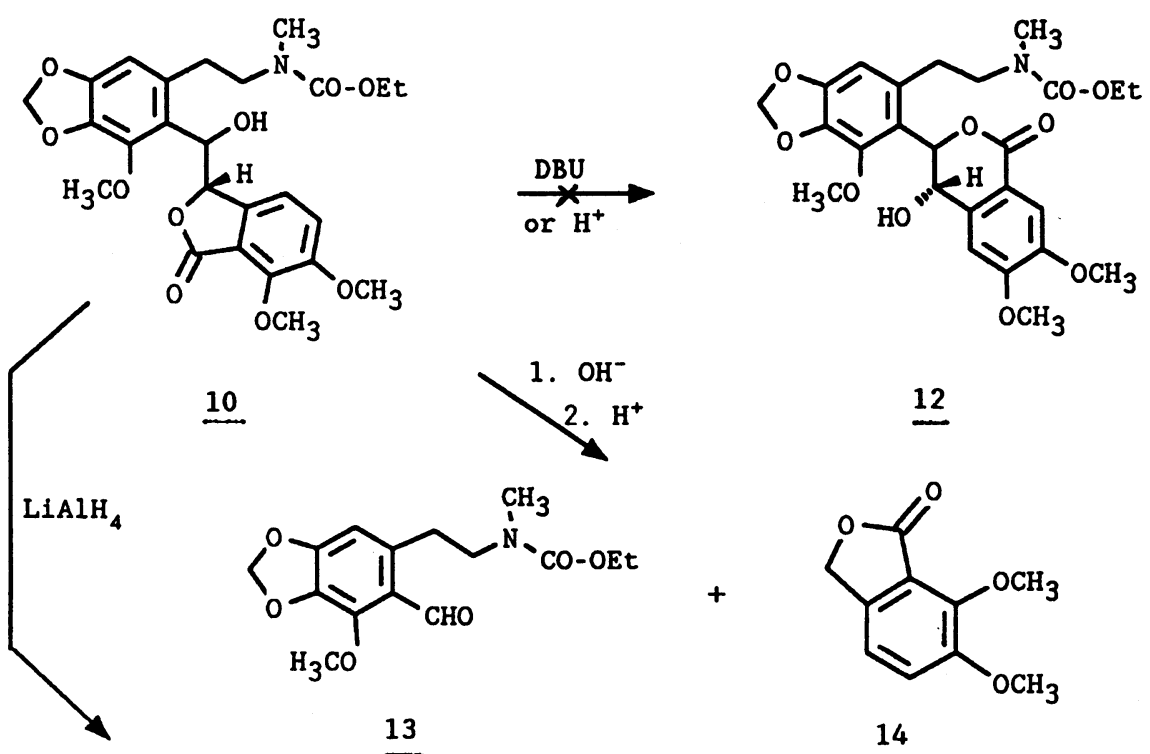

10

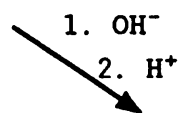

12

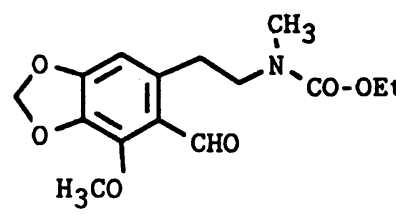

13

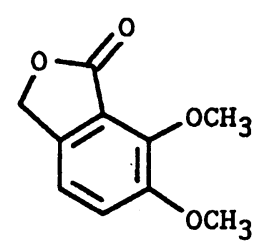

14

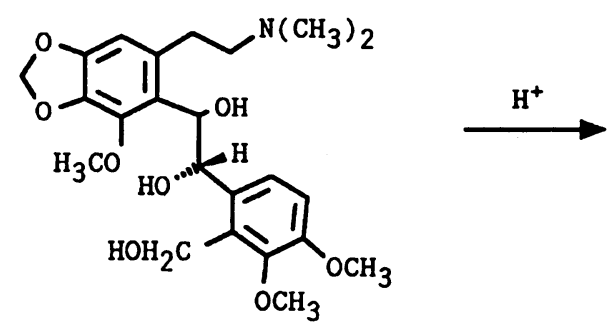

15<smiles>COc1ccc2c(c1OC)COC(c1c(CCN(C)C)cc3c(c1OC)OCO3)C2O</smiles>

16 
We tried to convert the 5-ring lactone of $\mathbf{1 0}$ into the 6-ring lactone of the 3-phenyl-isochroman-1-one 12 under basic conditions in order to determine the absol. configuration of the carbinol chiral center in 10 (intramolecular transesterification). These experiments failed: compound 10 was split to the aldehyde 13 and to meconine (14) because compound 10 is a phenylogous $\beta$-hydroxyketone sustaining aldol-cleavage. - When purified 10 was reduced by $\mathrm{LiAlH}_{4}$ to the triol 15 , which is homogenous according to its ${ }^{1} \mathrm{H}-\mathrm{NMR}$-spectrum, followed by $\mathrm{H}^{+}$-catalyzed ring closure to the 4-hydroxy-3-phenylisochroman 16, a 3:1 mixture of diastereomers arose. Therefore, this experiment does not indicate the absolute configuration at C-3 in $\mathbf{1 6}$ and - consequently - at the carbinol chiral centre of the hydroxy-urethan 10 .

In the course of $\alpha$-narcotine (5)-cleavage a hypothetic quarternary urethan $>\mathrm{N}^{+}\left(\mathrm{CH}_{3}\right)-\mathrm{CO}-\mathrm{OEt}$ is converted by external $\mathrm{Cl}^{-}$to the chloro-urethans, e.g. 9 (a quaternary urethan is an intermediate in the ECF-cleavage reaction of C-1-unsubstituted $\quad N$-methyl-1,2,3,4-tetrahydroisoquinolines ${ }^{11}$ ). This may occur by inversion, retention or via a resonancestabilized carbenium ion, followed by nucleophilic substitution under asymmetric induction exerted by the chiral centre at the lactone group. - In order to have an intramolecular nucleophile available, $\alpha$-narcotine (5) was converted to its sodium salt ${ }^{12}$, which was treated with $\mathrm{ECF} / \mathrm{KOH}$. We isolated a mixture of 9 and 10. Treatment of this sodium salt in the bomb tube led to 10 (main product) besides some 9. - ECF is known to activate carboxylate ions by conversion to mixed anhydrides ${ }^{13)}$. Probably an analogous reaction regenerated the lactone of $\alpha$-narcotine (5) which is cleaved by ECF (vide supra). When we tried to prevent this lactonization by treatment of the benzylic OH-group in $\alpha$-narcotine sodium salt with $\mathrm{CH}_{2} \mathrm{~N}_{2} / \mathrm{BF}_{3}$, or dimethyl sulfate under phase transfer conditions ${ }^{14)}$, or with dihydropyran ${ }^{15)}$ we obtained $\alpha$-narcotine (5), identical with authentic material. Formation of $\beta$ narcotine (6) was excluded by the ${ }^{1} \mathrm{H}-\mathrm{NMR}$-spectrum.

\section{Cleavage of (-)- $\beta$-hydrastine (7) with ECF}

(-)-B-Hydrastine (7) was treated with ECF as described for $\alpha$-narcotine (5), leading to two products. One compound reveals an enol-lactone absorption at $1775 \mathrm{~cm}^{-1}$ and shows an intensive bluish fluorescence. Its UV-spectrum $(\lambda \max =$ $378 \mathrm{~nm}$ ) is comparable with that of the analogous compound obtained by Klötzer ${ }^{16)}$ who degraded $\beta$-hydrastine (7) with phenyl chloroformate/diisopropyl-ethylamine $(\lambda \max =$ $385 \mathrm{~nm}$ ). Our analytical data (cf. Experim. Part) are in accordance with structure 17. Because Klötzer ${ }^{16)}$ has confirmed Z-configuration for his compound by $\mathrm{X}$-ray analysis, 17 is also a trans-stilbene. HPLC-analysis of the mother liquors of 17 indicated a 4:1-mixture of a second compound - [18] - with 17; this mixture could not be separated (vide infra). According to Beilstein's test and to its MS 18 contains chlorine. $\mathrm{M}^{+}$of 18 looses $\mathrm{HCl}$ to $\mathrm{m} / \mathrm{z} 455$, which<smiles>COc1ccc([C@H](O)[C@H]2c3c(cc4c(c3OC)OCO4)CCN2C)c([C@H](O)C2CCCCC2)c1OC</smiles>

Scheme 7

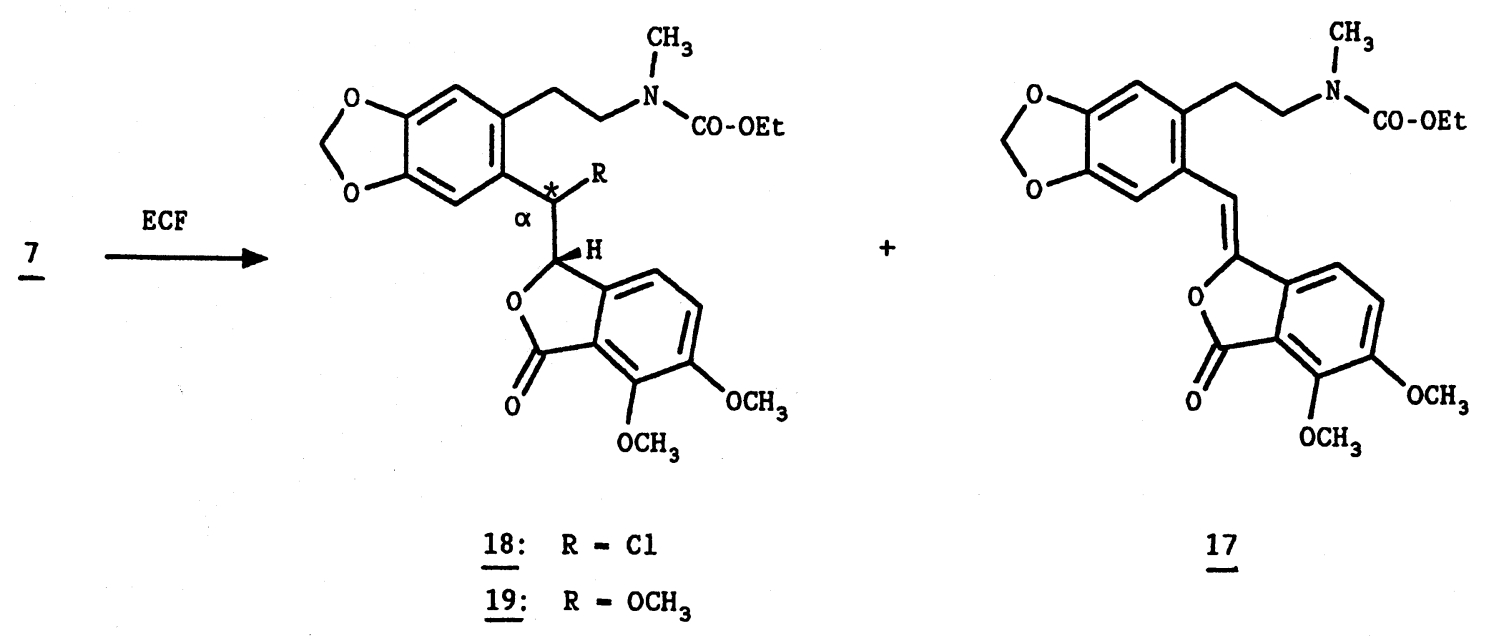


decomposes to $\mathrm{m} / \mathrm{z} 352$ (McLafferty). For further fragments cf. Experim. Part. - When we tried to separate 18 from 17 by HPLC, using $\mathrm{MeOH} /$ water $3: 1,18$ was converted to the methoxy-analogue 19.

Contrary to our results, Whaley ${ }^{17)}$ has obtained meconine (14) and $N$-carbethoxy-hydrastinine from $\beta$-hydrastine (7) with ECF, probably due to his more vigorous conditions during work-up. These may have led to an aldolcleavage analogous to that mentioned with the hydroxy-urethan 10. - Olofson et al. ${ }^{18)}$, however, obtained an enol lactone, analogous with 17 , when treating 7 with vinyl chloroformate.

\section{Experimental Part}

General Remarks: Melting points: Büchi 510 apparatus, uncorrected.Elemental analyses: Mikroanalytisches Laboratorium, University of Regensburg.- IR-spectra: Beckman Acculab 3; KBr.- ${ }^{1} \mathrm{H}-\mathrm{NMR}$ : Varian EM $360 \mathrm{~W}$, Varian EM 390, $\mathrm{CDCl}_{3}$, TMS as internal standard, $60 \mathrm{MHz}$, if not stated otherwise.- UV-spectra: Uvikon 810, Kontron.- Mass spectra: Varian MAT CH5 und 311A.

ECF-degradation of $\alpha$-narcotine (5): 3-\{[2-( $\beta-N$-Ethoxycarbonyl$N$-methyl-aminoethyl)-6-methoxy-4,5-methylenedioxyphenyl]-chloromethyl\}-6,7-dimethoxy-1(3H)-isobenzofuranone (9-1)

$0.41 \mathrm{~g}$ ( $1 \mathrm{mmole}$ ) of $\alpha$-narcotine (5) in $5 \mathrm{ml}$ of $\mathrm{CHCl}_{3} / \mathrm{Et}_{2} \mathrm{O}$ were shaken with $5 \mathrm{ml}$ of $15 \% \mathrm{KOH}$ and $0.8 \mathrm{ml}$ of ethyl chloroformate (ECF) for $2 \mathrm{~h}$ at room temp. This procedure was repeated, followed by shaking with $2.5 \mathrm{ml}$ of $\mathrm{KOH}$ for $1 \mathrm{~h}$ and standing overnight. The combined org. phases were extracted with $\mathrm{N} \mathrm{HCl}$, washed with water, dried $\left(\mathrm{Na}_{2} \mathrm{SO}_{4}\right)$ and evaporated: oily material, crystallization from $\mathrm{Et}_{2} \mathrm{O}$, recrystallization from benzene/petroleum ether: $0.38 \mathrm{~g}(74 \%)$ of 9-I, m.p. $118^{\circ} \mathrm{C},[\alpha]^{20} \mathrm{D}=-8^{\circ}\left(\mathrm{CHCl}_{3}\right)$.$\mathrm{C}_{25} \mathrm{H}_{28} \mathrm{ClNO}_{9}(521.9)$ calc. C $57.5 \mathrm{H} 5.41 \mathrm{Cl} 6.8$ found $\mathrm{C} 57.7 \mathrm{H} 5.51 \mathrm{Cl}$ 7.0.

HPLC-analysis: $\mathrm{SiO}_{2} ; \mathrm{CH}_{2} \mathrm{Cl}_{2} / \mathrm{Et}_{2} \mathrm{O}$ 1:4; Altex apparatus, pump $110 \mathrm{~A}$, detector Kontron $720 \mathrm{LC}, 256 \mathrm{~nm}$, integrator Shimadzu C-R1A, sample injector Rheodyne 7125 , flow $1.0 \mathrm{ml} / \mathrm{min}$.

Ir (KBr): $1695(\mathrm{CO}), 1760 \mathrm{~cm}^{-1}$ (CO).- MS: $\mathrm{m} / \mathrm{z}=521\left(\mathrm{M}^{+},{ }^{35} \mathrm{Cl}, 2 \%\right)$, $485\left(4,{ }^{*} 451.49\right), 418\left(3,{ }^{*} 335.36\right), 382\left(15,{ }^{*} 300.87\right), 328$ (12), 292 (18, *259.95), 264 (2), 225 (3), 220 (100), 205 (12, *191.02), 193 (6), 177 (2), 147 (3), 116 (7).- MS-HR: $\mathrm{C}_{12} \mathrm{H}_{14} \mathrm{NO}_{3}$ calc. 220.09732 found 220.09726.${ }^{1} \mathrm{H}-\mathrm{NMR}\left(90 \mathrm{MHz}, 50^{\circ} \mathrm{C}\right): \delta(\mathrm{ppm})=1.25\left(\mathrm{t} ; \mathrm{J}=7.0 \mathrm{~Hz}, 3 \mathrm{H},-\mathrm{CH}_{2}-\mathrm{CH}_{3}\right)$, 2.56-2.82 (m; 4H, - $\left.\mathrm{CH}_{2}-\right), 2.74\left(\mathrm{~s} ; 3 \mathrm{H},-\mathrm{NCH}_{3}\right), 3.82\left(\mathrm{~s} ; 3 \mathrm{H},-\mathrm{OCH}_{3}\right), 4.07$ $\left(\mathrm{s} ; 3 \mathrm{H},-\mathrm{OCH}_{3}\right), 4.09\left(\mathrm{~s} ; 3 \mathrm{H},-\mathrm{OCH}_{3}\right), 4.11\left(\mathrm{q}\right.$ of d; $\mathrm{J}_{\mathrm{q}}=7.0 \mathrm{~Hz}, \mathrm{~J}_{\mathrm{d}}=1.0 \mathrm{~Hz}$, $2 \mathrm{H},-\mathrm{CH}_{2}-\mathrm{CH}_{3}$ ), 5.00 (d; J = 9.3 Hz, $\left.1 \mathrm{H},-\mathrm{CH}-\mathrm{Cl}\right), 5.99,6.03(\mathrm{AB} ; \mathrm{J}=1.3$ $\mathrm{Hz}, 2 \mathrm{H},-\mathrm{O}-\mathrm{CH}_{2}-\mathrm{O}-$ ), 6.11 (dd; $\mathrm{J}_{1,2}=8.4 / 1.0 \mathrm{~Hz}, 1 \mathrm{H}$, arom.), 6.28 (d; J = $9.3 \mathrm{~Hz},-\mathrm{CH}-\mathrm{O}-$ ), 6.40 (s; 1H, arom.), 6.92 (d; J = $8.4 \mathrm{~Hz}, 1 \mathrm{H}$, arom.).- UV $(\mathrm{MeOH}): \lambda \max (\log \varepsilon)=214$ (4.58), 292 (sh; 3.60), $309 \mathrm{~nm}$ (3.66).

3-\{[2-(B-N-Ethoxycarbonyl-N-methyl-aminoethyl)-6-methoxy-4,5-methylenedioxy-phenyl]-hydroxymethyl]-6,7-dimethoxy-1(3H)-isobenzofuranone (10)

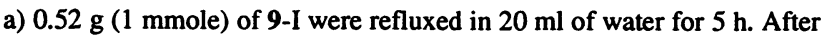
cooling and extraction with $\mathrm{CHCl}_{3}$, the org. phase was dried $\left(\mathrm{Na}_{2} \mathrm{SO}_{4}\right)$ and evaporated: colorless oil, crystals from $\mathrm{Et}_{2} \mathrm{O}: 0.46 \mathrm{~g}(91 \%)$ of 10, m.p. $101^{\circ} \mathrm{C},[\alpha]_{\mathrm{D}}^{20}=-49^{\circ}\left(\mathrm{CHCl}_{3}\right) .-\mathrm{C}_{25} \mathrm{H}_{29} \mathrm{NO}_{10}(503.5)$ calc. C $59.6 \mathrm{H} 5.81 \mathrm{~N}$ 2.8 found $\mathrm{C} 59.7 \mathrm{H} 5.87 \mathrm{~N}$ 2.6.- Spectral data are reported by Lee et al. ${ }^{8}$.

b) $0.52 \mathrm{~g}$ ( $1 \mathrm{mmole})$ of 9-I and $1.2 \mathrm{~g}(5 \mathrm{mmole})$ of freshly precipitated $\mathrm{Ag}_{2} \mathrm{O}$ were refluxed in dioxan for $24 \mathrm{~h}$. Work-up as described and column chromatography (cc) $\left(\mathrm{SiO}_{2} ; \mathrm{CHCl}_{3} / \mathrm{Et}_{2} \mathrm{O} 1: 1\right)$ afforded colorless crystals, identical with compound 10 obtained by procedure a).

\section{Reconversion of 10 to 9 -I}

$0.50 \mathrm{~g}$ ( $1 \mathrm{mmole})$ of 10 in $5 \mathrm{ml}$ of absol. $\mathrm{CHCl}_{3}$ were stirred with $0.14 \mathrm{~g}$ (1.2 mmole) of freshly distilled $\mathrm{SOCl}_{2}$ for $2 \mathrm{~h}$ at room temp. The mixture was poured into ice water. Extraction $\left(\mathrm{CHCl}_{3}\right)$, drying $\left(\mathrm{Na}_{2} \mathrm{SO}_{4}\right)$, evaporation, $\mathrm{cc}\left(\mathrm{SiO}_{2} ; \mathrm{CHCl}_{3} / \mathrm{Et}_{2} \mathrm{O} 1: 1\right)$, and crystallization $\left(\mathrm{Et}_{2} \mathrm{O}\right)$ led to $0.48 \mathrm{~g}$ (92\%) of 9-I, m.p. $118^{\circ} \mathrm{C},[\alpha]_{\mathrm{D}}^{20}=-8^{\circ}\left(\mathrm{CHCl}_{3}\right)$.

\section{Conversion of 9-1 to stilbene 11 (entry 6, Table 1)}

$0.10 \mathrm{~g}(0.2 \mathrm{mmole})$ of $9-\mathrm{I}$ in $5 \mathrm{ml}$ of absol. acetone were stirred with 0.30 $\mathrm{g}$ ( 2 mmole) of $\mathrm{NaI}$ at reflux temp. under $\mathrm{N}_{2}$ for $8 \mathrm{~h}$. After dilution with water and extraction $\left(\mathrm{CHCl}_{3}\right)$ stilbene 11 was obtained, identical with authentic material (see below).

3-[2-(B-N-Ethoxycarbonyl-N-methyl-aminoethyl)-6-methoxy-4,5-methylenedioxy-benzylidenyl]-6,7-dimethoxy-1(3H)-isobenzofuranond11)

$0.52 \mathrm{~g}$ ( $1 \mathrm{mmole})$ of 9-I and $0.15 \mathrm{~g}$ ( $1 \mathrm{mmole})$ of DBU in $10 \mathrm{ml}$ of absol. benzene were refluxed for $15 \mathrm{~h}$. After cooling and extraction with $2 \mathrm{~N} \mathrm{HCl}$ the org. phase was dried $\left(\mathrm{Na}_{2} \mathrm{SO}_{4}\right)$ and evaporated: yellow oil; purification by cc $\left(\mathrm{SiO}_{2} ; \mathrm{CHCl}_{3} / \mathrm{Et}_{2} \mathrm{O} 1: 1\right)$ produced crystals, recrystallization from benzene: $0.42 \mathrm{~g}(86 \%)$ of 11 , m.p. $170^{\circ} \mathrm{C}$.- $\mathrm{C}_{25} \mathrm{H}_{27} \mathrm{NO}_{9}$ (485.5) calc. $\mathrm{C} 61.8 \mathrm{H}$ 5.60 found C 61.7 H 5.65.- IR (KBr): 1695 (CO), $1775 \mathrm{~cm}^{-1}$ (CO).- MS: $\mathrm{m} / \mathrm{z}=485\left(\mathrm{M}^{+}, 88 \%\right), 467$ ( $\left.1,{ }^{*} 449.67\right), 383(69), 382$ (100, 302.45$), 369$ (26), 341 (19, *315.12), 292 (49), 264 (14, "238.68), 193 (58, "97.51), 189 (10), 116 (97).- ${ }^{1} \mathrm{H}-\mathrm{NMR}: \delta$ (ppm) $=1.17\left(\mathrm{t} ; \mathrm{J}=7 \mathrm{~Hz}, 3 \mathrm{H},-\mathrm{CH}_{2}-\mathrm{CH}_{3}\right)$, 2.55-4.10 (m; 6H, - $\left.\mathrm{CH}_{2-},-\mathrm{CH}_{2}-\mathrm{CH}_{3}\right), 2.76\left(\mathrm{~s} ; 3 \mathrm{H},-\mathrm{NCH}_{3}\right), 3.97(\mathrm{~s} ; 3 \mathrm{H}$, $\left.-\mathrm{OCH}_{3}\right), 4.03\left(\mathrm{~s} ; 3 \mathrm{H},-\mathrm{OCH}_{3}\right), 4.14\left(\mathrm{~s} ; 3 \mathrm{H},-\mathrm{OCH}_{3}\right), 5.92\left(\mathrm{~s} ; 2 \mathrm{H},-\mathrm{O}-\mathrm{CH}_{2}-\mathrm{O}-\right.$ ), 6.33 (s; 1H, arom.), 6.51 (s; 1H, vinyl-H), 7.30, 7.60 (AB; J = 9 Hz, 2H, arom.).- UV (MeOH): $\lambda \max (\log \varepsilon)=220(4.39), 283(4.10), 355 \mathrm{~nm}$ (4.11).

ECF-degradation of (-)- $\beta$-narcotine ((-)-6): 3-\{[2-( $\beta-N-$ Ethoxycarbonyl $N$-methyl-aminoethyl)-6-methoxy-4,5-methylenedioxyphenyl]-chloromethyl\}-6,7-dimethoxy-1-(3H)-isobenzofuranones (9-III and 9-IV)

$(-)-6$ was treated with ECF under the conditions used for the ECF-cleavage of (-)-5.- 9-IV was obtained by crystallization from absol. $\mathrm{Et}_{2} \mathrm{O}, 9$-III by cc $\left(\mathrm{SiO}_{2} ; \mathrm{CHCl}_{3} / \mathrm{Et}_{2} \mathrm{O} 1: 1\right)$ and crystallization from $\mathrm{Et}_{2} \mathrm{O}$.

9-III: m.p. $123^{\circ} \mathrm{C},[\alpha]^{20} \mathrm{D}=-7.5^{\circ}\left(\mathrm{CHCl}_{3}\right)$

9-IV: m.p. $120^{\circ} \mathrm{C},[\alpha]_{\mathrm{D}}^{20}=+7^{\circ}\left(\mathrm{CHCl}_{3}\right)$

\section{DBU-catalyzed cleavage of hydroxy-urethan 10}

$0.20 \mathrm{~g}$ ( $0.4 \mathrm{mmole})$ of 10 and $0.12 \mathrm{~g}(0.8 \mathrm{mmole})$ of $\mathrm{DBU}$ in $5 \mathrm{ml}$ of absol. dimethylformamide were heated to $120^{\circ} \mathrm{C}$ for $24 \mathrm{~h}$. After evaporation the residue was suspended in water, the mixture was acidified with $2 \mathrm{~N} \mathrm{HCl}$ and extracted with $\mathrm{CHCl}_{3}$. The org. phase was dried $\left(\mathrm{Na}_{2} \mathrm{SO}_{4}\right)$ and evaporated, the remaining oil was purified by $\mathrm{cc}\left(\mathrm{SiO}_{2} ; \mathrm{CHCl}_{3} / \mathrm{Et}_{2} \mathrm{O} 1: 1\right)$. Meconine (14) was obtained from that oil by sublimation $\left(160^{\circ} \mathrm{C} / 1\right.$ Torr) and crystallized from EtOH/water.- The aldehyde 13 crystallized from $\mathrm{Et}_{2} \mathrm{O} /$ water.

14: $0.055 \mathrm{~g}$ (71\%), m.p. $101^{\circ} \mathrm{C}$, lit. ${ }^{19)}: 102^{\circ} \mathrm{C}$.- IR (KBr): $1740 \mathrm{~cm}^{-1}$ (CO).- MS: $\mathrm{m} / \mathrm{z}=194\left(\mathrm{M}^{+}, 100 \%\right), 176\left(61,{ }^{*} 159.67\right), 165\left(94,{ }^{*} 140.34\right)$, 163 (16, $\left.{ }^{*} 136.95\right), 148\left(22,{ }^{*} 124.45\right), 147\left(62,{ }^{*} 122.78\right) .-{ }^{1}$ H-NMR: $\delta(\mathrm{ppm})$ $=4.01\left(\mathrm{~s} ; 6 \mathrm{H},-\mathrm{OCH}_{3}\right), 5.17\left(\mathrm{~s} ; 2 \mathrm{H},-\mathrm{CH}_{2}-\right), 7.13(\mathrm{~s} ; 1 \mathrm{H}$, arom.), $7.20(\mathrm{~s} ; 1 \mathrm{H}$, arom.).

\section{2-( $\beta$-N-Ethoxycarbonyl-N-methyl-aminoethyl)-6-methoxy-} 4,5-methylenedioxybenzaldehyde (13)

Yield $0.04 \mathrm{~g}(32 \%)$, m.p. $103^{\circ} \mathrm{C}$, lit. ${ }^{17)}: 104^{\circ} \mathrm{C}$. $\mathrm{IR}(\mathrm{KBr}): 1680 \mathrm{~cm}^{-1}$ (CO, CHO).- MS: $\mathrm{m} / \mathrm{z}=309$ ( $\left.\mathrm{M}^{+}, 3 \%\right), 291\left(14,{ }^{*} 274.05\right), 263$ (2), $236(6)$, $206\left(80,{ }^{*} 137.33\right), 193(7), 116(100)$. 


\section{Cleavage of 10 with p-toluenesulfonic acid}

$0.10 \mathrm{~g}$ ( $0.2 \mathrm{mmole})$ of 10 and 0.017 ( $\mathrm{g}(0.1 \mathrm{mmole})$ of $p$-toluenesulfonic acid in $10 \mathrm{ml}$ of absol. $\mathrm{CH}_{2} \mathrm{Cl}_{2}$ were stirred at room temp. for $48 \mathrm{~h}$. The solution was washed with $5 \% \mathrm{KOH}$, the org. phase was dried $\left(\mathrm{Na}_{2} \mathrm{SO}_{4}\right)$ and evaporated. From the remaining oil meconine (14) was obtained as described above.

2-(2-Hydroxymethyl-3,4-dimethoxyphenyl)-1-[2-( $\beta-N, N$-dimethylaminoethyl)-6-methoxy-4,5-methylenedioxylphenyl]-ethan-1,2-diola(15)

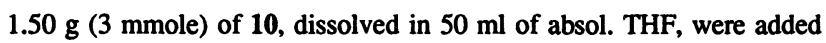

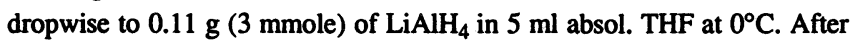
stirring for $3 \mathrm{~h}$ excess of $\mathrm{LiAlH}_{4}$ was destroyed by water. A saturated solution of $\mathrm{NH}_{4} \mathrm{Cl}$ was added drop by drop under vigorous shaking until the precipitate massed together. The org. phase was decanted, the precipitate was extracted several times with $\mathrm{CH}_{2} \mathrm{Cl}_{2}$. The org. phases were dried $\left(\mathrm{Na}_{2} \mathrm{SO}_{4}\right)$ and evaporated: colorless oil of $15 ; 1.20 \mathrm{~g}(89 \%),[\alpha]_{\mathrm{D}}^{20}=-69^{\circ}$ $\left(\mathrm{CHCl}_{3}\right)$.- $\mathrm{C}_{23} \mathrm{H}_{31} \mathrm{NO}_{8}$ (449.4).- IR (KBr): $3400 \mathrm{~cm}^{-1}$ (broad; OH).- ${ }^{1} \mathrm{H}$ NMR: $\delta(\mathrm{ppm})=2.13\left(\mathrm{~s} ; 6 \mathrm{H},-\mathrm{NCH}_{3}\right), 2.20-3.70\left(\mathrm{~m} ; 4 \mathrm{H},-\mathrm{CH}_{2}-\right), 3.82$ (s; $\left.9 \mathrm{H},-\mathrm{OCH}_{3}\right), 4.58\left(\mathrm{~s} ; 2 \mathrm{H},-\mathrm{CH}_{2}-\mathrm{OH}\right), 5.07,5.27(\mathrm{AB} ; \mathrm{J}=9 \mathrm{~Hz}, 2 \mathrm{H}$, $-\mathrm{CH}-\mathrm{OH}$ ), 5.85 (s; 2H, -O-CH $-\mathrm{O}-$ ), 6.27 (s; 1H, arom.), 6.75, 7.03 (AB; J $=9 \mathrm{~Hz}, 2 \mathrm{H}$, arom.). $\mathrm{UV}(\mathrm{MeOH}): \lambda \max (\log \varepsilon)=228(4.39), 283 \mathrm{~nm}$ (3.57).

4-Hydroxy-7,8-dimethoxy-3-[2-( $\beta-N, N-$ dimethyl-aminoethyl $)-6-m e t h o x y-$ 4,5-methylenedioxyphenyl]-isochroman(16)

$0.22 \mathrm{~g}(0.5 \mathrm{mmole})$ of 15 were refluxed in $2 \mathrm{~N} \mathrm{HCl}$ for $2 \mathrm{~h}$. After cooling the solution was adjusted to $\mathrm{pH} 8.5$ by $\mathrm{NaHCO}_{3}$ and extracted with $\mathrm{CHCl}_{3}$. The org. phase was dried $\left(\mathrm{Na}_{2} \mathrm{SO}_{4}\right)$ and evaporated. The oily material was purified by $\mathrm{cc}\left(\mathrm{Al}_{2} \mathrm{O}_{3}, \mathrm{AcOEt}\right)$ affording a colorless oil, which slowly crystallized from $\mathrm{Et}_{2} \mathrm{O}: 0.17 \mathrm{~g}(79 \%)$ of 16 , m.p. $88^{\circ} \mathrm{C},[\alpha]_{\mathrm{D}}^{20}=+9^{\circ}$ $\left(\mathrm{CHCl}_{3}\right.$ ).- $\mathrm{C}_{23} \mathrm{H}_{29} \mathrm{NO}_{7}$ (431.5).- IR (KBr): $3400 \mathrm{~cm}^{-1}$ (broad; OH).- MS: $\mathrm{m} / \mathrm{z}=413$ (100\%), 368 (12), 337 (7). - ${ }^{1} \mathrm{H}-\mathrm{NMR}(90 \mathrm{MHz}): \delta(\mathrm{ppm})=2.15$, 2.22 (2 x s; $\left.6 \mathrm{H},-\mathrm{NCH}_{3}\right), 2.28-2.60\left(\mathrm{~m} ; 4 \mathrm{H},-\mathrm{CH}_{2}-\right), 3.81,3.83,3.85,3.91$, $3.96\left(5 \mathrm{x} \mathrm{s} ; 9 \mathrm{H},-\mathrm{OCH}_{3}\right), 5.14,5.37\left(\mathrm{AB} ; \mathrm{J}=13.4 \mathrm{~Hz}, 2 \mathrm{H},-\mathrm{CH}_{2}-\mathrm{O}-\right), 5.30$ (s), 5.79 (s), 5.92 (s; - CH-O-), 5.93, $5.95\left(\mathrm{AB} ; \mathrm{J}=1.4 \mathrm{~Hz}, 2 \mathrm{H},-\mathrm{O}-\mathrm{CH}_{2}-\mathrm{O}-\right.$ ), 6.27, 6.66 (AB; J = 8.3 Hz, arom. $\mathrm{H}$ ), 6.38, 6.49, 6.55, 6.73, 6.75 (AB, s; arom. $\mathrm{H}$ ) (all together $3 \mathrm{H}$, arom.).- ${ }^{1} \mathrm{H}-\mathrm{NMR}$ (60 MHz, $\mathrm{d}_{6}$-benzene): $\delta$ $(\mathrm{ppm})=2.05 ; 2.15\left(2 \mathrm{x} \mathrm{s} ; 6 \mathrm{H},-\mathrm{NCH}_{3}\right), 3.27,3.33\left(2 \times \mathrm{s} ; 3 \mathrm{H},-\mathrm{OCH}_{3}\right), 3.55$, $3.60\left(2 \times \mathrm{s} ; 3 \mathrm{H},-\mathrm{OCH}_{3}\right), 3.73,3.82\left(2 \times \mathrm{s} ; 3 \mathrm{H},-\mathrm{OCH}_{3}\right)$.- UV $(\mathrm{MeOH}): \lambda$ $\max (\log \varepsilon)=288 \mathrm{~nm}(4.00)$.

\section{ECF-Degradation of $\alpha$-narcotine Na-salt}

0.45 ( 1 mmole) of 5-Na-salt ${ }^{12)}$ were treated with ECF as described for 5 (vide supra).- The oil so obtained was separated by $\mathrm{cc}\left(\mathrm{SiO}_{2} ; \mathrm{CHCl}_{3} / \mathrm{Et}_{2} \mathrm{O}\right.$ 1:1).

fraction 1: chloro-urethan 9-I $(0.23 \mathrm{~g}, 44 \%)$

fraction 2: hydroxy-urethan $10(0.25 \mathrm{~g}, 50 \%)$

ECF-Degradation of $\beta$-hydrastine (7): 3-[2-( $\beta$-Ethoxycarbonyl-N-methylaminoethyl)-4,5-methylenedioxy-benzylidenyl]-6,7-dimethoxy-1(3H)isobenzofuranone (17), 3-\{[2-( $\beta-N-E$ thoxycarbonyl-N-methyl-aminoethyl)4,5-methylenedioxyphenyl]-chloromethyl\}-6,7-dimethoxy-1(3H)-isobenzofuranone (18), and 3-\{[2-( $\beta-N-$ Ethoxycarbonyl-N-methylaminoethyl)4,5-methylene-dioxyphenyl]-methoxymethyl\}-6,7-dimethoxy-

$1(3 H)$-isobenzofuranone (19)

$0.38 \mathrm{~g}$ ( $1 \mathrm{mmole})$ of 7 were treated with ECF as described for $\alpha$-narcotine (5).- The crystals obtained after usual work-up were suspended in a few $\mathrm{ml}$ of $\mathrm{Et}_{2} \mathrm{O}$ and filtered: 17: $0.19 \mathrm{~g}(42 \%)$, m.p. $147-148^{\circ} \mathrm{C}$.$\mathrm{C}_{24} \mathrm{H}_{25} \mathrm{NO}_{8}$ (455.5) calc. C $63.3 \mathrm{H} 5.53$ found $\mathrm{C} 63.5 \mathrm{H}$ 5.43.- $\mathrm{IR}(\mathrm{KBr})$ :
1690 (CO), $1775 \mathrm{~cm}^{-1}$ (CO).- MS: $\mathrm{m} / \mathrm{z}=455\left(\mathrm{M}^{+}, 68 \%\right), 352(100$, "272.32), 337 (20), 311 (26), 262 (16), 193 (29), 116 (61).- ${ }^{1}$ H-NMR: $\delta$ $(\mathrm{ppm})=1.27\left(\mathrm{t} ; \mathrm{J}=7 \mathrm{~Hz}, 3 \mathrm{H},-\mathrm{CH}_{2}-\mathrm{CH}_{3}\right), 2.80-4.33(\mathrm{~m} ; 6 \mathrm{H},-\mathrm{CH}-$, $\left.-\mathrm{CH}_{2}-\mathrm{CH}_{3}\right), 2.90\left(\mathrm{~s} ; 3 \mathrm{H},-\mathrm{NCH}_{3}\right), 3.99\left(\mathrm{~s} ; 3 \mathrm{H},-\mathrm{OCH}_{3}\right), 4.17(\mathrm{~s} ; 3 \mathrm{H}$, $\left.\mathrm{OCH}_{3}\right), 6.00\left(\mathrm{~s} ; 2 \mathrm{H},-\mathrm{O}-\mathrm{CH}_{2}-\mathrm{O}-\right), 6.72(\mathrm{~s} ; 1 \mathrm{H}$, vinyl-H), 6.83-7.80 (m; $4 \mathrm{H}$, arom.).- UV (MeOH): $\lambda \max (\log \varepsilon)=223$ (4.33), 242 (sh; 4.26), 305 (4.04), $378 \mathrm{~nm}$ (4.18).- Evaporation of the etheral solution (vide supra) led to crystals containing stilbene 17 and the chloromethyl derivative $18(4: 1)$.

18: $\mathrm{C}_{24} \mathrm{H}_{26} \mathrm{ClNO}_{8}$ (491.9).- IR (KBr): 1680 (CO), $1780 \mathrm{~cm}^{-1}$ (CO).- MS: $\mathrm{m} / \mathrm{z}=491\left(\mathrm{M}^{+},{ }^{35} \mathrm{Cl}, 2 \%\right), 455\left(37,{ }^{*} 421.64\right), 446$ (2), 410 (2), 388 (15), 352 (48, "272.32), 339 (17), 311 (12), 298 (41), 262 (23, "230.35), 193 (43), 116 (100).- MS-HR: $\mathrm{C}_{24} \mathrm{H}_{26} \mathrm{ClNO}_{8}$ : calc. 491.13470 found 491.13579.- ${ }^{1} \mathrm{H}-\mathrm{NMR}: \delta(\mathrm{ppm})=1.28\left(\mathrm{t} ; \mathrm{J}=7 \mathrm{~Hz}, 3 \mathrm{H},-\mathrm{CH}_{2}-\mathrm{CH}_{3}\right), 2.57$ 4.00 (m; $\left.5 \mathrm{H},-\mathrm{CH}_{2-},-\mathrm{CH}-\mathrm{Cl}\right), 2.88\left(\mathrm{~s} ; 3 \mathrm{H},-\mathrm{NCH}_{3}\right), 3.92\left(\mathrm{~s} ; 3 \mathrm{H},-\mathrm{OCH}_{3}\right)$, $4.08\left(\mathrm{~s} ; 3 \mathrm{H},-\mathrm{OCH}_{3}\right), 4.18\left(\mathrm{q} ; \mathrm{J}=7 \mathrm{~Hz}, 2 \mathrm{H},-\mathrm{CH}_{2}-\mathrm{CH}_{3}\right), 5.63$ (s; br., $1 \mathrm{H}$, -O-CH-), 5.97 (s; 2H, -O- $\left.\mathrm{CH}_{2}-\mathrm{O}-\right), 6.60-7.47$ (m; 4H, arom.).- UV $(\mathrm{MeOH}): \lambda \max$ (qual.) $=219 ; 242(\mathrm{sh}) ; 298 \mathrm{~nm}$.

Analytical HPLC (RP 18; $\mathrm{MeOH} /$ water 3:1 and $\mathrm{Si} \mathrm{60;} \mathrm{CH}_{2} \mathrm{Cl}_{2} / \mathrm{Et}_{2} \mathrm{O} 4: 1$ ) indicated that 18 is converted to the methoxymethyl derivative 19 by MeOH. 19 was isolated by prep. HPLC (RP 18, MeOH/water 3:1): colorless oil.

19: $\mathrm{C}_{25} \mathrm{H}_{29} \mathrm{NO}_{9}$ (487.5).- IR (film): 1690 (CO), $1760 \mathrm{~cm}^{-1}$ (CO).- MS: $\mathrm{m} / \mathrm{z}=445$ (1\%), 410 (6), 294 (100), $262\left(92,{ }^{*} 233.48\right), 234$ (32, $\left.{ }^{*} 208.99\right)$.${ }^{1} \mathrm{H}-\mathrm{NMR}: \delta(\mathrm{ppm})=1.30\left(\mathrm{t} ; \mathrm{J}=7 \mathrm{~Hz}, 3 \mathrm{H},-\mathrm{CH}_{2}-\mathrm{CH}_{3}\right), 2.47-4.00(\mathrm{~m} ; 5 \mathrm{H}$, $-\mathrm{CH}_{2-},-\mathrm{O}-\mathrm{CH}-$ ), 2.92 (s; $3 \mathrm{H},-\mathrm{NCH}_{3}$ ), 3.37 (s; $\left.3 \mathrm{H},-\mathrm{CH}-\mathrm{OCH}_{3}\right), 3.93$ (s; $\left.3 \mathrm{H},-\mathrm{OCH}_{3}\right), 4.08\left(\mathrm{~s} ; 3 \mathrm{H},-\mathrm{OCH}_{3}\right), 4.20\left(\mathrm{q} ; \mathrm{J}=7 \mathrm{~Hz}, 2 \mathrm{H},-\mathrm{CH}_{2}-\mathrm{CH}_{3}\right), 5.57$ (d; J $=6 \mathrm{~Hz}, 1 \mathrm{H},-\mathrm{O}-\mathrm{CH}-$ ), 6.02 (s; $2 \mathrm{H},-\mathrm{O}-\mathrm{CH}_{2}-\mathrm{O}-$ ), 6.67, 7.22 (AB; J = 9 $\mathrm{Hz}, 2 \mathrm{H}$, arom.), 6.73 (s; 1H, arom.), 6.83 (s; 1H, arom.).- UV (MeOH): $\lambda$ $\max (\log \varepsilon)=242(\operatorname{sh} ; 3.69), 288 \mathrm{~nm}(3.26)$.

\section{Literatur}

1 J. Gadamer and F. Knoch, Arch. Pharm. (Weinheim) 259, 135 (1921).

2 F. v. Bruchhausen and J. Knabe, Arch. Pharm. (Weinheim) 287, 601 (1954).

3 J. Knabe and U.R. Shukla, Arch. Pharm. (Weinheim) 295, 690 (1962).

4 W. Wiegrebe, Pharm. unserer Zeit 16, 69 (1987).

5 S. v. Angerer, E. Eibler, D.U. Lee, and W. Wiegrebe, Sci. Pharm. 57, 1 (1989).

6 P. Kerekes and G. Gaál, Acta Chim. Acad. Sci. Hung. 103, 343 (1980).

7 K. Sasvari, L. Parkanyi, P. Kerekes, and R. Bognar, Acta Cryst. B35, 986 (1979).

8 D.U. Lee, K. Iwasa, M. Kamigauchi, N. Takao, and W. Wiegrebe, Chem. Pharm. Bull. 39, 1944 (1991).

9 K.K. Mayer, S. Prior, and W. Wiegrebe, Monatsh. Chem. 117, 533 (1986).

10 H. Günther, NMR-Spektroskopie, p. 103, G. Thieme Verlag, Stuttgart 1973.

11 D.U. Lee and W. Wiegrebe, Arch. Pharm. (Weinheim) 319, 694 (1986).

12 P. Rabe and A. McMillan, Liebigs Ann. Chem. 377, 223 (1910).

13 R. Geiger, Chem. unserer Zeit 7, 131 (1973).

14 A. Merz and G. Märkl, Angew. Chem. 85, 867 (1973).

15 D.N. Robertson, J. Org. Chem. 25, 931 (1960).

16 W. Klötzer, S. Teitel, and A. Brossi, Helv. Chim. Acta 55, 2228 (1972).

17 W.M. Whaley and M. Meadow, J. Org. Chem. 19, 666 (1954).

18 R.A. Olofson, R.C. Schnur, L. Bunes, and J.P. Pepe, Tetrahedron Lett. $1977,1567$.

19 G.A. Edwards, W.H. Perkin jr., and F.W. Stoyle, J. Chem. Soc. C $1925,195$. 